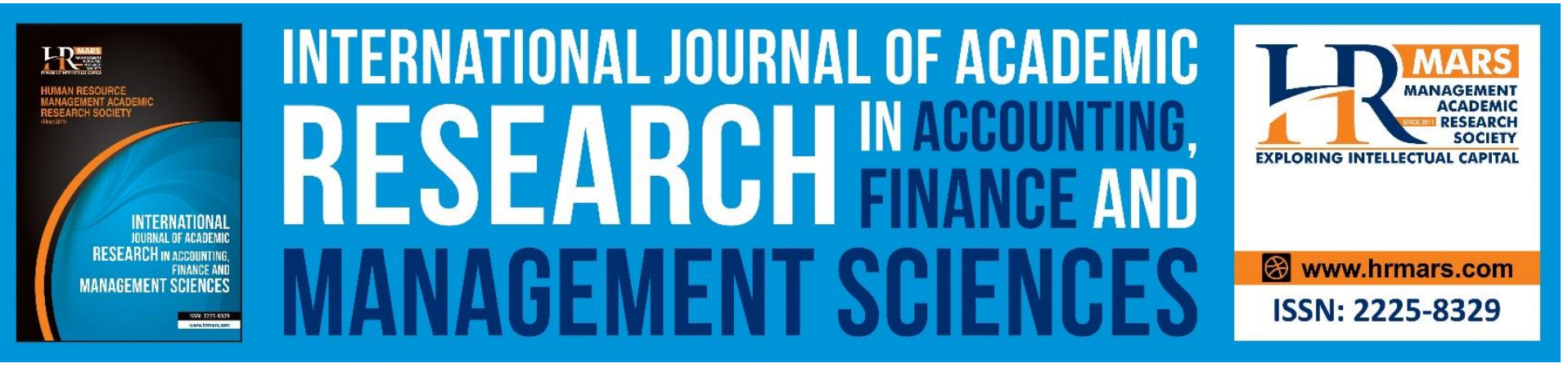

\title{
The Moderating Effect for Forensic Accounting on the Relationship between corporate Governance and Quality of Accounting Information in The Jordanian Public Shareholding Companies
}

\author{
Ali Alaoubi, Mohammad Abdullah Almomani
}

To Link this Article: http://dx.doi.org/10.6007/IJARAFMS/v11-i2/9663

DOI:10.6007/IJARAFMS /v11-i2/9663

Received: 06 March 2021, Revised: 10 April 2021, Accepted: 30 April 2021

Published Online: 20 May 2021

In-Text Citation: (Alaoubi \& Almomani, 2021)

To Cite this Article: Alaoubi, A., \& Almomani, M. A. (2021). The Moderating Effect for Forensic Accounting on the Relationship between corporate Governance and Quality of Accounting Information in The Jordanian Public Shareholding Companies. International Journal of Academic Research in Accounting Finance and Management Sciences, 11(2), 47-61.

\section{Copyright: (C) 2021 The Author(s)}

Published by Human Resource Management Academic Research Society (www.hrmars.com)

This article is published under the Creative Commons Attribution (CC BY 4.0) license. Anyone may reproduce, distribute, translate and create derivative works of this article (for both commercial and non-commercial purposes), subject to full attribution to the original publication and authors. The full terms of this license may be seen at: http://creativecommons.org/licences/by/4.0/legalcode

Vol. 11, No. 2, 2021, Pg. 47 - 61 


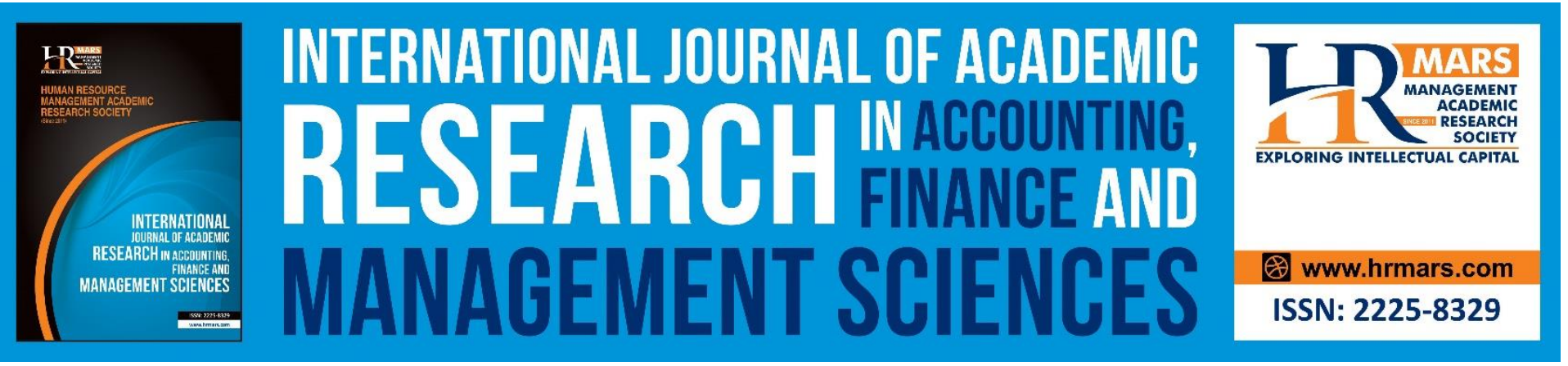

\title{
The Moderating Effect for Forensic Accounting on the Relationship between corporate Governance and Quality of Accounting Information in The Jordanian Public Shareholding Companies
}

\author{
Ali Alaoubi \\ Master student, Accounting Department, Jadara University-Jordan. \\ Email: alzoubiali1982@gmail.com \\ Mohammad Abdullah Almomani \\ Professor, Accounting Department, Jadara University-Jordan. \\ Email:momani@jadara.edu.jo
}

\begin{abstract}
This study aimed to find out the moderating effect for forensic accounting on the relationship between corporate governance and quality of accounting information in the Jordanian public shareholding companies, where the study population consisted of all external certified accountants, while the study sample consisted of a random sample of external certified accountants. Where (217) questionnaires distributed to external certified accountants. After applying the multiple regression equation and hierarchical regression equation test on the study data. The results were reached, the existence of a statistically significant impact on the application of governance rules in its dimensions (commitment of corporate governance to shareholder rights, commitment of corporate governance to equal treatment among shareholders, commitment of corporate governance to disclosure and transparency, commitment of corporate governance to responsibilities The Board of Directors) on the quality of accounting information, and there is also a modified effect of forensic accounting with statistical significance on the relationship between the application of corporate governance rules in its dimensions and the quality of accounting information with its elements (The relevance and the faithful representation of the accounting information) in the Jordanian public shareholding companies. The study recommends the necessity of continuing commitment of boards of directors in companies to the application of governance rules and laying down the necessary and strict controls to ensure their implementation. And also the necessity of holding training courses for certified accountants specialized in the field of Forensic Accounting.
\end{abstract}

Keywords: Forensic Accounting, Corporate Governance Rules, Quality of Accounting Information, Relevance, Faithful Representation. 
INTERNATIONAL JOURNAL OF ACADEMIC RESEARCH IN ACCOUNTING, FINANCE AND MANAGEMENT SCIENCES

Vol. 11, No. 2, 2021, E-ISSN: 2225-8329 @ 2021 HRMARS

\section{Introduction}

This study aims to demonstrate the modified impact of forensic accounting on the relationship between the application of corporate governance rules in its dimensions, and the quality of accounting information with its characteristics (relevance and the faithful representation) in Jordanian public joint-stock companies, from the point of view of external certified accountants. As a result of the recent financial crisis that occurred in 2008, the level of confidence that shareholders and other stakeholders place in the financial reports issued by public joint-stock companies decreased (Ismail, 2010). Authors and experts attributed these effects and repercussions to the phenomenon of financial corruption that spread in these companies, which prompted boards of directors to give priority to their private interest at the expense of the interests of shareholders and parties related to the companies they manage. With regard to financial corruption, several reasons standing behind this phenomenon. The most important reason is the absence of corporate governance systems, or their lack of enforcement and implementation on the ground. Another reason of corruption is the absence of legislation and laws necessary to hold boards of directors accountable in these companies (Khatataba, 2014). The application of corporate governance rules ensures transparency and disclosure of the various information contained in the financial reports, and establishes protection and safety systems for the rights of the parties associated with the company, which should be constantly informed about the financial position of companies, which requires clarity of all related details to the financial information. and enhances the confidence of stakeholders in the company, which allows it to continue and achieve a competitive advantage (Ali et al., 2012), (Al-Ramahi, Barakat \& Shahwan, 2014; Susanto, 2015). The governance has focused on enhancing the quality of accounting information through two characteristics of information; relevance and faithful representation in the financial report data, as all as the relevant parties in the company (investors, lenders, creditors ,,, etc.), which showed the importance of the financial information that companies disclose. (The Organization for Economic Co-operation and Development, 2015).

The activation of the corporate governance rules issued by the OECD is one of the necessities that should be focused on activating them, given the positive effects they have on companies and stakeholders, and among the justifications for the existence of corporate governance (Love, 2011; Chibarinya, 2014; Elhabib, Abdul Rashid \& Basiruddin, 2015) according to agency theory, the ownership and management of the institution is separated, and that governance is based on the performance of the board of directors. Good management guarantees the optimal use of a company's assets for the sake of the company's interest and objectives, and achieves several benefits and profit for investors. Thus, the application of corporate governance plays an important role in preserving capital and improving institutional performance from the economic side, which is reflected positively on the level of Social welfare, and the value of the company. This separation reduces the losses that may be incurred when there is no separation between ownership and management.

The financial reports are among the responsibilities of management as it shows the results of accounting operations of firms by the end of accounting period, and it shows all the information and details that provide benefits to shareholders, current and future investors, lenders, creditors, and many parties related to the company, and they are used to evaluate the performance of the board of directors and administrators, and evaluate the extent of its efficiency in exploiting the available resources (Alsalim \& Hama-Amin, 2016). 
INTERNATIONAL JOURNAL OF ACADEMIC RESEARCH IN ACCOUNTING, FINANCE AND MANAGEMENT SCIENCES

Vol. 11, No. 2, 2021, E-ISSN: 2225-8329 @ 2021 HRMARS

The quality of accounting information in the financial reports reflects the level of credibility of this information, and ensures its integrity and provides beneficial information to different interested parties. Several aspects of information are involved in the financial reports including; results of operations, investment, marketing, and financial activities. In addition, the financial reports present accounting information related to the different economic aspects. The activities of firms is normally affected by the political consideration (Wang \& Liang, 2008). The quality of accounting information refers to the set of characteristics that should be available in accounting information, such as the suitability and honest representation of the operations, in order to become feasible, and to achieve the required benefits from financial reports. (Alsalim, \& Hama-Amin \& Sultan, 2016).

As a result of changes and developments occurred in the work environment and different businesses, that caused more diversity in dealings among firms, keeping pace with the various developments in the accounting field, and evaluating their impact on the social, economic, legal, and technological aspects, became necessary. This led to the emergence of judicial accounting, which depends on the use of various experiences in the accounting field for judging the related issues, so the emergence of this field has led to strengthening the judicial rulings, investigations related to fraud, fraud, settlements and dispute resolution (Wadad and Bakr, 2014). Forensic accountability plays an important role in activating governance; therefore, various evaluations related to the legal and professional records associated with the company are dealt with, in addition, through judicial accounting, problems in accounting events are revealed through financial data, information and reports, which calls for the existence of systems and laws that allow clarity and transparency in the data provided. This calls for a change in organizational structures, work procedures, and ensuring the efficiency of workers in these institutions, and their ability to adhere to the principles of corporate governance (Mohd-Sanusi et al., 2015).

The forensic accounting of the important mechanisms that employ accounting competencies to detect discrepancies in the actual and expected financial performance, processes and activities, where the results appearing in numbers within the financial statements and reports, which requires making sure that accountants should have enough judicial experience and skills in order to be able to deal with issues, and suspects, to understand the motives and causes standing behind such practices (Van Akkeren \& Buckby, 2017).

Burghul (2015); Abbas, Mezher and Hamid (2019) demonstrated the existence of an impact of forensic accounting and corporate governance in restricting creative accounting methods. The authors stated that judicial accountability has a large and effective role and contributes in decreasing financial fraud. They also found that forensic accounting is an important mean in curbing creative accounting and restricting the pursuit of practices, through which, tricks and practices are used to conceal the actual performance to achieve the benefits employees. The activation of forensic accounting makes firms committed to apply accounting standards in its various activities and practices, such as documenting financial and accounting operations, and committed to ethical administrative performance that includes the compatibility of what is documented in the financial statements with the actual performance of the company, and highlighting this clarity by implementing various financial standards and indicators, and acquiring public confidence (Sule, Ibrahim \& Sani, 2019).The importance of forensic accounting is that it is one of the means that achieve integration between accounting and laws, and it makes investigations related to accounting issues and lawsuits in a better form. This enhances the role of the forensic accountant in providing 
INTERNATIONAL JOURNAL OF ACADEMIC RESEARCH IN ACCOUNTING, FINANCE AND MANAGEMENT SCIENCES

Vol. 11, No. 2, 2021, E-ISSN: 2225-8329 ๑ 2021 HRMARS

advice and achieving justice in accounting cases and contributes in reducing fraudulent practices (Nuolam, Onyema \& Ekeke, 2016). It is also one of the means by which numbers are referred to, studied and analyzed, where this opens the way for more studies and research in accounting (Siregar \& Tenoyo, 2015), (Barzan and Khalaf, 2016). Abbas and Hamid (2019) defined forensic accounting as an integrated mixture of accounting sciences and auditing with the investigative skills of the forensic accountant, as it represents more appropriate accounting to the legal point of view, because of its high levels of assurance.

The importance of this study lies in demonstrating the importance of integration between governance and forensic accounting in enhancing the quality of accounting information, which will positively affect the parties related to firms such as shareholders, investors, creditors, ... etc. Activating forensic accounting is one of the requirements at present, which should be applied to various economic sectors, and it is one of the means by which the results of information quality can be more insured. The role of a forensic accountant, based on OECD, is to cover all data related to the case, where accounting protects the ownership of domestic and foreign shareholders, and large and small shareholders (Huber, 2013).

It should be noted that the positive reflection of applying corporate governance on the quality of accounting information cannot be achieved unless all legal, organizational and accounting procedures are met, in order to prepare and submit financial reports and data that achieve accuracy, clarity, credibility, and confidence in institutional results, in addition to activating control mechanisms. To prepare financial reports and statements, and to ensure that members of the board of directors, shareholders, and associated parties, adhere to the application of corporate governance rules.

\section{Prior Researches}

- Burghul (2015), examined the statement of the complementary relationship between forensic accounting and corporate governance and their role in reducing financial and administrative corruption in Jordanian public shareholding companies. It found that forensic accounting provides the tools and means that enable the forensic auditor to investigate cases of fraud and fraud practiced in companies and that it contributes in reducing the practices of financial and administrative corruption.

-Al-Suwaidawi (2015), examined the effect of corporate governance on the level of disclosure of accounting information in service companies. The study based on a sample consisting of (92) firm managers and internal audit managers. The results of the study showed that there is an effect of the principles of governance at the level of disclosure on accounting information of service firms. It discloses accounting errors and methods of treatment, and the existence of an effective basis for implementing legislation that guarantees the interests of shareholders.

-Karawani (2015), examined the contributions of governance in achieving quality in financial information and accounting disclosure, and how to benefit from it. The study is based on a sample consisting of (90) financial employees and accountants working in firms. It found that there is a positive and statistically significant correlation between corporate governance and financial information, its quality level, and the importance of disclosure.

Al-Abdi. (2016), investigated the impact of corporate governance on the quality of accounting information. The study sample consisted of (17) accounting and financial employees of firms. The 
INTERNATIONAL JOURNAL OF ACADEMIC RESEARCH IN ACCOUNTING, FINANCE AND MANAGEMENT SCIENCES

Vol. 11, No. 2, 2021, E-ISSN: 2225-8329 @ 2021 HRMARS

study showed that there is a strong and positive correlation between corporate governance mechanisms applied on firms and the quality of accounting information.

- Al-Najjar and Akl (2016), examined the impact of firm commitment in Palestine Stock Exchange to apply corporate governance rules on their financial performance. The study was based on a sample of 36 public shareholding listed firms, and used the data covering the period 2009-2014 of these included firms within the sample. The study found a positive significant impact of corporate governance measures on measures of financial performance, including return on assets; book value per share; and firm market value.

Al-Hayari (2017), carried out a study aiming for revealing the impact of applying corporate governance principles in enhancing the reliability of financial reports issued by joint-stock industrial companies listed at the Amman Stock Exchange. The study was conducted on a sample of (125) financial intermediaries, financial managers, and external auditors. The results showed that there is a significant effect of the principles of corporate governance on the level of the financial reports confidence issued by industrial firms in securities market.

The study of Fateh and Abdul-Ghani (2018), aimed to identify how to combat judicial accountability against fraud and to identify how it can be reduced. The study sample consisted of 34 institutions. The results of the study showed that spreading the culture of interest in judicial accountability plays its role and importance in reducing financial fraud and fraud, and that the interest in providing legal work services for forensic accounting helps in preventing fraud and financial fraud.

- Hammoudi and Saeed's study (2018), aimed at demonstrating forensic accounting strategies in restricting creative accounting practices, in addition to clarifying the most important means and techniques used in this issue. It found that the creative accounting practices are many, and intend to manipulate the financial statements by choosing accounting policies that are appropriate. The goals of the company's owners, such as tax evasion, and that forensic accounting are among the fields of accounting specialized in clarifying the obligations that result from the actual or expected accumulations between the conflicting parties in the court.

Stamp Study (2019), objected for revealing the role of forensic accounting in the processes of investigation and financial auditing, based on a random sample consisted of 47 certified accountants. The results showed that there is a role for judicial accountability in cases related to the financial aspect in the courts. It also showed that courts are recommended to create a specialized forensic accounting unit in its capital structure.

Abbas, Mezher and Hamid (2019), carried out a study for the purpose of explain the relationship between forensic accounting and governance, in addition to the role it plays in restricting creative accounting. The sample of the study consisted of 42 academics and auditors. The results showed that there is an effect of forensic accounting and corporate governance in restricting creative accounting methods.

-The study of Siam and Abdullah (2019), objected for demonstrating the effect of applying forensic accounting in managing profits of public joint-stock companies, and the extent of applying forensic accounting techniques on profit management from the standpoint of certified accountants. The study concluded that related application level techniques for forensic accounting in public firms of Jordan, 
INTERNATIONAL JOURNAL OF ACADEMIC RESEARCH IN ACCOUNTING, FINANCE AND MANAGEMENT SCIENCES

Vol. 11, No. 2, 2021, E-ISSN: 2225-8329 @ 2021 HRMARS

was high by the viewpoints of certified accountants, and it affects management practices to manage profits in public shareholding firms.

The purpose of the study of Oyedokun (2015), was to show the main activity of the forensic accountant, which includes multiple activities to solve complex financial problems resulting from fraud and outside the work of the legal accountant. The results of the study showed that forensic accounting is considered a preventive profession and offers a high level of confidence in the various services that it provides to beneficiaries, in addition to the importance of the procedures that are used in the forensic accounting profession in the different forms of financial fraud practices..

-Azzoz (2016), carriedou a study to show the impact of governance on the quality of profits for the listed firms at Amman Stock Exchange. The study was conducted based on a sample consisting of 73 listed firm at Amman Stock Exchange using data covering the period (2007-2012). The study concluded that the size and the activities of the audit committee have to be activated with both the quality of profits and the management of profits.

Rehman \& Hashim (2017), carried out a study at the purpose of revealing the impact of forensic accounting on the maturity of corporate governance by activating the mediating effect of internal auditing. The results of the study showed that there is a role of forensic accounting in activating the principles of governance by focusing on achieving company's goals and ensuring the safety of operational performance that arising from firm's efficiency.

Alsalim, Amin \& Youssef (2018), investigated the role that corporate governance plays in achieving the quality of accounting information. The study concluded that that there is an impact of governance on the dimensions of transparency and disclosure as components of accounting information. It also found that there is an effect of the role of boards of directors on activating corporate governance. The study indicated the necessity of activating forensic accounting to ensure a positive impact on preparing financial statements and raising the level of transparency and disclosure.

Rehman \& Hashim (2018), studied the forensic accounting at the purpose of showing the impact of forensic accountability in revitalizing corporate governance in the Sultanate of Oman. The study found a positive impact of judicial accountability in activating corporate governance in Oman.

Sule, Ibrahim \& Sani (2019), carried out a study aimed to reveal the impact of the forensic accountant on the investigation of the detection of financial fraud. Results revealed that judicial accountability has a role in revealing financial fraud, fraud and exploitation, in addition to its role in controlling the practices and behaviors of board members of firms.

\section{Study Hypoteses}

Based on the survey and review of the prior related researches, it is perceived that some studies focused on corporate governance and its relationship with accounting disclosure, such as Al-Sewaidi (2015), and Karawani (2015), while other studies concentrated on governance relation with quality reports, such as Alsalim, Amin \& Youssef (2018), and Azzoz (2016). Moreover, it is noted that some prior researched gave attention to the importance of forensic accounting and its relationship with governance, such as Rehman \& Hashim (2017), and Abbas, Mazhar and Hamid (2019). The current study is an extension to prior researches, but it is distinguished from those because it deals with three 
variables including, judicial accounting, corporate governance, and the quality of accounting information. The current study aims to determine the modified effect of forensic accounting on the relationship between corporate governance and the quality of accounting information of the Jordanian public shareholding firms from the view point of view of external legal accountants, where this type of studies has its importance in enhancing the performance of public shareholding firms. Therefore, the conclusions of the study will be of high importance, for managements of business organizations, since it contributes in developing the literature and improves the practice when itsconclusions are adopted.

\section{Study Hypotheses}

Based on the survey and review of the prior researches and its findings, It is concluded that some studies investigated corporate governance relationship with accounting disclosure, such as AlSewaidi study (2015), and Karawani (2015), while other studies investigated corporate governance relationship with quality reports, such as Alsalim, Amin \& Youssef (2018), and Azzoz (2016). In addition, some prior studies focused on the importance of forensic accounting and its relationship with governance, such as a Rehman \& Hashim (2017), and Abbas, Mazhar and Hamid (2019). The current study is an extension of the prior studies, but it is distinguished from those when it concentrates on three variables including, judicial accounting, corporate governance, and accounting information quality. It examines whether forensic accounting has a modified effecton the relationship between corporate governance and the quality of accounting information in Jordanian public shareholding companies, from the standpoints of certified public accountants, because of the importance of this issue in improving performance of public shareholding firms, especially because the findings of the study enriches the theoretical framework of the subject. The hypotheses of the study, in its null form, are listed as follows.

H01: There is no significant effect of the application of corporate governance rules in dimensions of; shareholder rights, shareholders' equality, disclosure and transparency, and boards' responsibilities, on the quality of accounting information.

H02: There is no significant modified effect of forensic accounting on the relationship between the application of corporate governance rules in dimensions of; shareholder rights, shareholders' equality, disclosure and transparency, boards' responsibilities, on the quality of accounting information.

\section{Study Methodology}

The current study adopted the descriptive and analytical approach, to find out the amended effect of forensic accounting on the relationship between corporate governance and the quality of accounting information in Jordanian public shareholding companies. The population of the study includes all of the working certified public accountants in Jordan. The survey shows that there are in total 305 in job certified public accountants by the end of 2020. Therefore, a sample consisted of 217 had been selected using the random sampling method. The primary data for the study is collected from respondents using the questionnaire research instrument. Cronbach Alpha had been used to test the stability and internal consistency of data collected from respondents, where the test shows 95.9 percent. This value of Cronbach Alfa is considered high when compared with the acceptable value that equals 70 percent (Tighiza, 2009). 
INTERNATIONAL JOURNAL OF ACADEMIC RESEARCH IN ACCOUNTING, FINANCE AND

MANAGEMENT SCIENCES

Vol. 11, No. 2, 2021, E-ISSN: 2225-8329 @ 2021 HRMARS

\section{Descriptive Analysis of the Study Variables}

The 5-point Likert scale had been followed in the questionnaire development, where a definite number is given to each possible selection among the 5 alternatives that the respondent can select a single alternative for each item. The $5^{\text {th }}$ alternatives are given grades as follows.

\begin{tabular}{|l|l|}
\hline Choice & Weight \\
\hline Strongly agree & 5 \\
\hline Agree & 4 \\
\hline Neither agree, Nor disagree & 3 \\
\hline Disagree & 2 \\
\hline Strongly disagree & 1 \\
\hline
\end{tabular}

Table 2, shows the arithmetic mean and the standard deviation of each included variable in the study.

Table (2): The arithmetic means and standard deviations of the study variables

\begin{tabular}{|l|l|l|l|l|}
\hline $\begin{array}{c}\text { Item } \\
\text { number }\end{array}$ & \multicolumn{1}{|c|}{ Item name } & \multicolumn{1}{|c|}{$\begin{array}{c}\text { Variable } \\
\text { type }\end{array}$} & $\begin{array}{c}\text { Arithmetic } \\
\text { mean }\end{array}$ & $\begin{array}{l}\text { Standard } \\
\text { deviation }\end{array}$ \\
\hline 1 & $\begin{array}{l}\text { Corporate governance commitment to } \\
\text { shareholders' rights }\end{array}$ & independent & 4.052 & 0.677 \\
\hline 2 & $\begin{array}{l}\text { Corporate governance commitment to equal } \\
\text { treatment between shareholders }\end{array}$ & independent & 4.042 & 0.599 \\
\hline 3 & $\begin{array}{l}\text { Corporate governance commitment to } \\
\text { disclosure and transparency }\end{array}$ & independent & 4.190 & 0.614 \\
\hline 4 & $\begin{array}{l}\text { Commitment of corporate governance to the } \\
\text { responsibilities of the board of directors }\end{array}$ & independent & 4.201 & 0.603 \\
\hline 5 & Quality of accounting information & dependent & 4.120 & 0.445 \\
\hline 6 & Forensic Accounting procedures & Moderating & 3.923 & 0.628 \\
\hline
\end{tabular}

\section{Testing the Hypotheses of the Study}

Before testing the hypotheses, the possibility of linear overlap existence among the variables, had been used, where the test shows that there is no linear interference among variables. The results of correlation test showed supporting finding to the finding of linear overlap, when the correlations among the independent variables were less than 80 percent. Moreover, variance Inflation Factor (VIF), and tolerance variance were used to ensure that the data is appropriate, and can lead to study credibility. The entire values support study credibility. The coefficients of inflation of variation were greater than 1 and less than 10, in addition to the variation values allowed were limited to between 0.1 and 1 , which means the integrity of the study variables of the linear interference problems.

\section{Testing the First Hypothesis}

Table 3, shows the results of the related regression analysis for the $1^{\text {st }}$ hypothesis. The table shows that the coefficient of determination $\left(R^{2}\right)$ equals $75.5 \%$, which means that 75.5 percent of the change taking place in the quality of accounting information is due to the application of corporate governance rules in all its dimensions including, commitment of corporate governance to the rights of Shareholders, the company's governance commitment to equal treatment among shareholders, the company's governance commitment to disclosure and transparency, the company's governance 
INTERNATIONAL JOURNAL OF ACADEMIC RESEARCH IN ACCOUNTING, FINANCE AND MANAGEMENT SCIENCES

Vol. 11, No. 2, 2021, E-ISSN: 2225-8329 @ 2021 HRMARS

commitment to the responsibilities of the board of directors. The computed F-Value as a measure indicated by $F=163.749$ ), with a moral significance of less than $1 \%$. Based on which means rejecting the null hypothesis and accepting the alternative hypothesis that It states, "There is a statistically significant impact at the level of significance $(\alpha \leq 5 \%)$ for the application of governance rules in its dimensions on the quality of accounting information in Jordanian public joint-stock companies." This result was in agreement with the study of (Al-Abdi,2016) and (Hamidat and et al,2016)

Table (3)

The results of the first main hypothesis test

\begin{tabular}{|l|l|l|l|}
\hline \multirow{2}{*}{$\begin{array}{l}\text { Independent } \\
\text { variables }\end{array}$} & \multicolumn{3}{|l|}{ Statistical results of the first hypothesis test (H01) } \\
\cline { 2 - 4 } & $\mathrm{B}$ & $\mathrm{T}$ & Sig. \\
\hline $\begin{array}{l}\text { Constant } \\
\text { Shareholders' } \\
\text { equity }\end{array}$ & 1.028 & 8.235 & $0.000^{* * *}$ \\
\hline Equal treatment & 0.182 & 5.44 & $0.000^{* * *}$ \\
\hline $\begin{array}{l}\text { Transparency } \\
\text { disclosure }\end{array}$ & 0.149 & 9.172 & $0.000^{* * *}$ \\
\hline $\begin{array}{l}\text { Responsibilities of } \\
\text { the Board of } \\
\text { Directors }\end{array}$ & 0.144 & 3.505 & $0.001^{* * *}$ \\
\hline $\mathrm{R}^{2}$ & 3.234 & $0.001^{* * *}$ \\
\hline Adjusted $\mathrm{R}^{2}$ & & $75.50 \%$ \\
\hline Sig & $75.10 \%$ \\
\hline $\mathrm{F}$ & & $0.000^{* * *}$ \\
\hline
\end{tabular}

$* *$, the hypothesis is accepted at the significance level $5 \%, * * *$, the hypothesis is accepted at the significance level $1 \%$

The table also shows that the most influencing governance rule on the dependent variable, is corporate governance commitment towards shareholders' equality treatment, since the related Beta value for this variable is the highest, and equals 0.278 , where the $t$-value regarding this independent is 9.172. Based on the impact strength, independent variables are ranked as follows; shareholders' equality treatment, commitment corporate governance with shareholders' rights, disclosure, transparency, and board responsibilities, .

\section{The Second Hypothesis Test}

Table (4) shows the results of the multiple regression test when the modified variable (the procedures performed by the forensic accountant), is inserted to the dimensions of corporate governance, represented by, commitment towards shareholders' rights, commitment towards shareholders' treatment, corporate governance commitment towards disclosure and transparency, and corporate governance commitment towards the firm. With regard to board of directors responsibility, the test reveals that the related $\mathrm{R}^{2}$ to this variable increased by 1.3 percent, and became equals $76.8 \%$. The regression model representing the second main hypothesis is significant because $f$-value equals 76.273, and the computed coefficient of significance is less than 1 percent. Because the related coefficient of significance is less than 0.05 , the null hypothesis is rejected, where instead its 
INTERNATIONAL JOURNAL OF ACADEMIC RESEARCH IN ACCOUNTING, FINANCE AND MANAGEMENT SCIENCES

Vol. 11, No. 2, 2021, E-ISSN: 2225-8329 @ 2021 HRMARS

alternative is accepted. Using different words, the attest shows that there is a modified effect of judicial accounting on the relationship between the application of corporate governance rules and the quality of accounting information in Jordanian public shareholding firms.

Table (4)

The results of the second hypothesis test

\begin{tabular}{|l|l|l|l|}
\hline \multirow{2}{*}{ Independent variables } & \multicolumn{3}{l|}{$\begin{array}{l}\text { Statistical } \\
\text { hypothesults } \text { of the first }\end{array}$} \\
\cline { 2 - 4 } & $\mathrm{B}$ & $\mathrm{T}$ & \multicolumn{1}{l}{ Sig. } \\
\hline Constant & 2.723 & 4.524 & $0.000^{* * *}$ \\
\hline Shareholders' equity & 0.607 & 3.3902 & $0.001^{* * *}$ \\
\hline Equal treatment & 0.564 & 3.239 & $0.001^{* * *}$ \\
\hline Transparency disclosure & 0.778 & 3.164 & $0.002^{* * *}$ \\
\hline Responsibilities of the Board of Directors & 0.663 & 2.358 & $0.019^{* *}$ \\
\hline Forensic Accounting & 0.329 & 2.008 & $0.046^{* *}$ \\
\hline Shareholders' equity*Forensic Accounting & 0.094 & 2.035 & $0.043^{* *}$ \\
\hline Equal treatment*Forensic Accounting & 0.121 & 2.689 & $0.008^{* * *}$ \\
\hline Transparency disclosure*Forensic Accounting & 0.179 & 2.802 & $0.006^{* * *}$ \\
\hline $\begin{array}{l}\text { Responsibilities of the Board of Directors*Forensic| } \\
\text { Accounting }\end{array}$ & 0.155 & 2.133 & $0.034^{* *}$ \\
\hline $\mathrm{R}^{2}$ & & & $76.80 \%$ \\
\hline Adjusted R Square & & & $75.80 \%$ \\
\hline Sig & & & $0.000^{* * *}$ \\
\hline F & & & 76.273 \\
\hline
\end{tabular}

**, the hypothesis is accepted at the significance level 5\%,***, the hypothesis is accepted at the significance level $1 \%$

Table 4, also shows that the results of multiple regression when the modified variable of forensic accounting is inserted to the dimensions of the corporate governance, represented by corporate governance commitment towards shareholders' rights, corporate governance commitment towards shareholders' equality treatment, corporate governance commitment towards disclosure and transparency, and corporate governance commitment towards the firm. The related coefficient of determination $\left(\mathrm{R}^{2}\right)$ to the variable of the Board of Directors increased by 1.3 percent, and became equals $76.8 \%$. The study model representing the second main hypothesis is significant since $f$-value as equals 76.273 , and the coefficient of significance is less than $1 \%$. Because the computed coefficient of significance is higher than the predetermined one, which equals 0.05 , the null hypothesis is rejected, where the alternative one is accepted instead. In other words, the test shows that there is a modified significant effect of judicial accounting on relationship between the application of corporate governance rules and the quality of accounting information in Jordanian public shareholding companies.

It is clear from the table that the rule most influencing the dependent variable after entering the modified variable (the procedures that the judicial accountant performs) is the commitment of the company's governance to disclosure and transparency, where the value of ((Beta) was (0.179), and the value $(T=2.802$ ) with a less statistically significant level From $1 \%$ to the modified variable represented by the modified effect of the procedures carried out by the forensic accountant on the relationship between the company's governance commitment to disclosure, transparency and the 
INTERNATIONAL JOURNAL OF ACADEMIC RESEARCH IN ACCOUNTING, FINANCE AND MANAGEMENT SCIENCES

Vol. 11, No. 2, 2021, E-ISSN: 2225-8329 ๔ 2021 HRMARS

quality of accounting information, which means that there is a positive impact with statistical significance of the modified effect of the procedures performed by the forensic accountant on the relationship between the company's governance commitment to disclosure and transparency And the quality of accounting information.

It was determined above that the most influencing independent variable is corporate governance commitment towards shareholders' equal treatment. Table 4, shows that the independent variable of corporate governance commitment towards boards responsibilities, when forensic accounting inserted, directly comes next to shareholders' equal treatment, because the related beta equals 0.155 , and t-value equals. Because the coefficient of significance regarding the modified effect of forensic accounting procedures on the relationship between corporate governance commitment towards boards responsibilities and the quality of accounting information, the null hypotheses is rejected, and its alternative is accepted. This result means that there is a significant positive impact of the modified effect of the procedures performed by the forensic accountant on the relationship between the corporate governance commitment towards boards Responsibilities the quality of accounting information.

The third variable according to the strength of effect, when forensic accounting is inserted as a modified factor is corporate governance commitment towards shareholders' equal treatment, where the value of Beta is 0.0 .121 , and t-value equals 2.689, with 0.121 coefficient of significance. These statistics indicate that there is a significant positive impact of the modified effect of the actions taken by the forensic accountant, on the corporate government commitment relationship with shareholders equal treatment quality of accounting information.

The fourth variable according to the impact strength on the dependent variable, when the forensic accounting is inserted as a modifier, is corporate governance commitment towards shareholders' rights. Hypotheses testing indicate that the related Beta value to this independent is 0.094, and tvalue equals 2.035, while the coefficient of significance is less than 005 . Because $t$-value is less than 5 percent, the null hypothesis is rejected, whereas its alternative is accepted. This means that there is a significant positive impact of the modified effect of the procedures performed by the judicial accountant on the relationship between the commitment of the company's governance towards the rights of shareholders, and the quality of accounting information.

\section{Findings and Recommendations}

The study aimed to determine the impact of forensic accounting on the relationship between corporate governance and the quality of accounting information in Jordanian public shareholding companies. The study found that a significant impact is existed of corporate governance applications, in its dimensions of; shareholder rights, equality among shareholders, disclosure and transparency, and the responsibilities of the board of directors. With regard to the quality of accounting information in Jordanian public joint-stock companies, the more adherence to corporate governance rules, the higher the quality of accounting information. The existence of modified effect of forensic accounting has a significance effect on the relationship between the application of corporate governance rules, in its various dimensions, and the quality of accounting information in Jordanian public shareholding companies. This means that the procedures carried out by judicial accountants affect the nature of the relationship between the application of corporate governance rules in its different dimensions and the quality of accounting information. Also, the study found that forensic accounting had a positive effect in increasing its impact when combined with the application of governance rules, on 
INTERNATIONAL JOURNAL OF ACADEMIC RESEARCH IN ACCOUNTING, FINANCE AND

MANAGEMENT SCIENCES

Vol. 11, No. 2, 2021, E-ISSN: 2225-8329 @ 2021 HRMARS

the quality of accounting information, based on the value of $R^{2}$, and there is an integrative relationship between them. Based on the results the study recommends the necessity to continue applying the corporate governance procedures in Jordanian public shareholding companies, with follow-up by the Securities Commission and the Amman Stock Exchange to activate the application of corporate governance rules, and set the necessary and strict controls to ensure their implementation, as it reflects positively on the quality of accounting information, which positively affects the decisions of users of financial statements. It also recommends the necessity to hold training courses for the specialized certified accountants in the field of forensic accounting, to increase their experience with the procedures they perform, by developing them in line with the issues at hand. The need for cooperation by boards of directors is also recommended, and their support to forensic accountants is required. The last recommendation or authors, practitioners, academics, et al, to study this issue more in future.

\section{References}

Al-Abdi, D. (2016). Corporate governance and its role in achieving the quality of accounting information: a case study of the Algerian Alliance Insurance Company. Unpublished PhD thesis. Mohamed Khaider University, Algeria.

Al-Hiyari, O. (2017). The effect of applying the principles of corporate governance in enhancing the reliability of the financial reports issued by the joint stock industrial companies listed on the Amman Stock Exchange. Unpublished MA thesis, Middle East University, Jordan.

Ali, S., Rehana, K., Muhammed, A. \& Hussein, M. (2012). Corporate Governance Impact and Ownership Structure in Company on Financial Performance and Involving Behavior Risk. International Research Journal of Finance and Economics, 93: 44-55.

Al-Ramahi, N., Barakat, A., \&Shahwan, Y. (2014). The Impact of Corporate Governance Principles Application on Financial Performance of Public Shareholding Companies Listed in Amman Stock Exchange. European Journal of Accounting Auditing and Finance Research, 2(6), 100-117.

Alsalim, A., \& Hama-Amin, O. \& Sultan, A. (2016). Adaptation of Accounting Information System for the Requirements of Developing Accounting Measurement and Disclosure. European Journal of Business and Management, 8(9), 217-224.

Alsalim, A., \& Hama-Amin, O. (2016). Evaluating the Efficiency of the Internal Control System in Light of the Introduction of Computers. Research Journal of Finance and Accounting, 7(16), 30-41.

Alsalim, M., Amin, A., \& Youssef, A. (2018). The Role of Corporate Governance in AchievingAccounting Information Quality (Field Study In The Mishraq Sulfur Satate Co.). Studies and Scientific Researches, Economics Edition, 1: 1-24.

Al-Suwaidawi, M. (2015). Institutional governance and its impact on the level of disclosure in accounting information: a field study on service companies listed on the Amman Stock Exchange. Unpublished MA thesis, Zarqa University, Jordan.

Anuolam O., Onyema T., \&Ekeke, U. (2016). Forensic Accounting and Financial Crisis in Nigeria. West African Journal of Industrial and Academic Research, 1(17), 1-12.

Azzoz, A., \&Khamees, B. (2016). The Impact of Corporate Governance Characteristics on Earning and Earning Management; Evidence from Jordan. Jordan Journal of Business Administration, 12(1),187-207.

Barzan, S., and Khalaf, Q. (2016). The role of forensic accountingmethods to reduce fraud and manipulation. Journal of Management and Economics, 108: 221-236. 
INTERNATIONAL JOURNAL OF ACADEMIC RESEARCH IN ACCOUNTING, FINANCE AND

MANAGEMENT SCIENCES

Vol. 11, No. 2, 2021, E-ISSN: 2225-8329 @ 2021 HRMARS

Bulgur, L. (2015). The role of criminal accounting and corporate governance and the complementary relationship between them in reducing financial and administrative corruption in Jordanian public shareholding companies. A magister message that is not published. Middle East University, Jordan.

Chibarinya, K. (2014). Corporate governance notes. Zimbabwe: Kudzai.

Dawood, I., and Mahmoud, B. (2014). The role of forensic accounting in governance and its implications for the quality of accounting information, Journal of Accounting and Financial Studies - Al-Mustansiriya University, (9), Chapter Three, Issue.(28) .

Elhabib, M., Abdul Rashid, S., \&Basiruddin, R. (2015). Why does corporate governance become so important? An attempt to identify the major causes for calls to improve corporate governance. European Journal of Business and Management, 7(31), 122-125.

Fatih, witness and Abdulghani, close. (2018). Judicial accountability as a mechanism to reduce financial fraud and fraud. Unpublished master's thesis, Hama Al-Shaheed University of Lakhdar El-Wadi. Algeria.

Huber, W. (2013). Forensic Accountants, Forensic Accounting Certifications, and Due Diligence. Journal of Forensic \& Investigative Accounting, 5(1), 182-203.

Karawani, O. (2015). The impact of applying corporate governance on the quality of financial information and accounting disclosure. Unpublished MA Thesis, QasdiMerbah University, Algeria.

Mohd-Sanusi, Z., Rameli, M., Omar, N., \& Ozawa, M. (2015). Governance Mechanisms in the Malaysian Banking Sector: Mitigation of Fraud Occurrence. Asian Journal of Criminology, 10(3), 231-250.

OECD. (2015). G20/OECD principles of corporate governance. Available on the internet: https://www.oecd.org/daf/ca/Corporate-GovernancePrinciples-ENG.pdf.

Oyedokun, G. (2015). Forensic Investigation and Forensic Audit Methodology in a Computerized Work Environment. n SSRN Electronic Journal-Investigation and Forensic Audit Methodology, 1: 1-20.

Rehman, A., \& Hashim, F. (2017). Forensic Accounting on Corporate Governance Maturity mediated by Internal Audit: A Conceptual Overview. Forensic Sci Sem, 8(1), 10-18

Rehman, A., \& Hashim, F. (2018). Impact of Mature Corporate Governance on Detective Role of Forensic Accounting: Case of Public Listed Companies in Oman. FGIC $2^{\text {nd }}$ Conference on Governance and Integrity - KnE Social Sciences, DOI 10.18502/kss.v3i22.5080, 637-665.

Siregar, S., \&Tenoyo, B. (2015). Fraud Awareness Survey of Private Sector in Indonesia. Journal of Financial Crimes, 22(3), 329-346.

Sule, S., Ibrahim, S., \& Sani, A. (2019). The Effect of Forensic Accounting Investigation in Detecting Financial Fraud: A Study in Nigeria. International Journal of Academic Research in Business and Social Sciences, 9(2), 545-553.

Susanto, A. (2015). Influence The Quality Of Accounting Information On The Implementation Good Study Program Governance. International Journal of Scientific \& Technology Research, 4(12), 326-335.

The Secret of the Seal, Abeer. (2019). The role of forensic accounting in financial auditing and arbitration in the Kingdom of Saudi Arabia. World Journal of Economics and Business, 6 (3), 486 495.

Tigiza, M. (2009) the logical structure of Kronbach's alpha coefficient, and its accuracy in estimating reliability in light of the assumptions of measurement models, King Saud University Journal, 
INTERNATIONAL JOURNAL OF ACADEMIC RESEARCH IN ACCOUNTING, FINANCE AND

MANAGEMENT SCIENCES

Vol. 11, No. 2, 2021, E-ISSN: $2225-8329$ @ 2021 HRMARS

Article 21, Educational Sciences and Islamic Studies(3) Jordanian Association of Legal Accountants (2020). On Line.Available. (26 Apr.). http://www.jacpa.org.jo

Van Akkeren, J., \& Buckby, S. (2017). Perceptions on the Causes of Individual and Fraudulent Cooffending: Views of Forensic Accountants. Journal of Business Ethics, 146: 383-404.

Wang, B., \& Liang, X. (2008). Corporate Governance, Financial Conditions and Quality of Information Disclosure: Evidence from Chinese Shenzhen Stock Exchange. Accounting Research, (2), 31-38. 